\title{
The Spirit of Togetherness in Library Resource Sharing Among Indonesia Islamic Universities
}

\author{
Pungki Purnomo \\ Department of Library and Information \\ Science, Universitas Islam Negeri Syarif \\ Hidayatullah \\ Jakarta, Indonesia \\ pungki.purnomo@uinjkt.ac.id
}

\author{
Fadhilatul Hamdani \\ Department of Library and Information \\ Science, Universitas Islam Negeri Syarif \\ Hidayatullah \\ Jakarta, Indonesia \\ fadhilatul.hamdani@uinjkt.ac.id
}

\author{
Abdul Hafiz Dinullah \\ Department of Library and Information \\ Science, Universitas Islam Negeri Syarif \\ Hidayatullah \\ Jakarta, Indonesia \\ abdulhafizdinull lahegmail .com
}

\begin{abstract}
There are two objectives of this study. First is to investigate the impact of togetherness spirit in resource sharing program among Indonesia Islamic university libraries on the internal aspects of each library and the other one is its impact on the external aspects of library members collectively. The findings of this study internally that spirit of togetherness through library resource sharing program becomes the main argument to convince the university leaders to support the library to build institutional repository and also using the latest advancements of information technology tools. Externally that togetherness spirit through the establishment of the association of Indonesia Islamic universities libraries (APPTIS) is able to be collective efforts as communication medium among them and also attract the directorate of Islamic higher education to support the association objectives. However factually it is not easy for the association to implement their objectives optimally in practice.
\end{abstract}

Keywords-Indonesia state Islamic university libraries; Library Resource Sharing; UIN Jakarta; UIN Yogyakarta, UIN Malang.

\section{INTRODUCTION}

Library has significant role in supporting the university vision and mission especially in both teaching and research activities [1]. Today, libraries services are not only required to store and retrieve paper-based information, but also they must strive to provide information using the advancement technologies [2]. The era of information explosion makes users increasingly expect the libraries must be able to be providers of information[3]. Actually that library effort through resource sharing could be able to enhance their excellent service and competitiveness. As a tool for information interchange that library togetherness can overcome the various limitations of libraries to increase the quality service of academic education [4].

However, with the constraints of economic situation, space, manpower and the current advancements in information technology, librarians are required with the need to continuously innovate their library services [5]. Unfortunately, not always what the user expect to the libraries could be accomplished by the libraries. In another word it means that no libraries in the world could be independent in meeting user information needs. It clearly indicates that the need to resource sharing program for libraries become a must [6].

There are at least two similar studies on library collaboration to this research. The first was the research that has been conducted a long time with the title of the study was "Library Cooperation and Information Network". The objectives of this study were intended to reveal reasons for the need of cooperation and some areas of cooperation that need should be done and also some obstacles that could be barriers for sustainability of the cooperation program [7]. The other one is the research that was conducted in 2013. The study was entitled "Library Consortium in Indonesia". The objectives of the study were the type of library consortium that could be allowed to be done by libraries, some benefits that could be obtained from the formation of the library consortium and some obstacles of library cooperation were also identified [8].

That togetherness spirit in library resource sharing program means that each library member is required to share equally the resources one another. That it requires each library member must prepare the supporting factors that needed for sharing each other. Through the participation of libraries in the resource sharing program it could be able to force themselves not only to evaluate but also to complete their strengths and weaknesses of library capability for such purpose. Logically, that the success of the resource sharing program requires the equality of the members in various aspects such as human resource skills, financial resources, and also the use of the latest information technology communication advancements. Internally that togetherness spirit allows each library to evaluate itself. On the basis of the evaluation results then the library could argue the decision makers in the level of university and convince them to support the library for improving its capacity in order to be able to involve in the program of library resource sharing network. Externally, the spirit of togetherness among the state Islamic university libraries with the establishment of the association could be able to attract the intention of the directorate of Islamic higher education to assist the association activities that aims to improve their library quality services.

\section{METHOD}

This research was done in three different locations of state 
Islamic university libraries. They are state Islamic university library Jakarta, Yogyakarta and Malang. The qualitative method used in this study with the phenomenology approach. This approach was used in order to describe the general understanding of several individuals on their various experiences related to the concept [9]. The primary source of this study collected through observation and in-depth interview not only individually but also in the form of focus group discussion or panel [10, p. 135]. The criteria of the informants in this study are those who are considered competent and they also should be directly involved and experienced in running the library resource sharing program in their libraries.

\section{RESULT AND DisCUSSION}

As mentioned before, that togetherness spirit of resource sharing program among the state Islamic university libraries has the impact on the internal and external aspects. In term of internal aspect that togetherness spirit in library resource sharing give most the state Islamic university libraries a chance to dialogue with the university decision makers about the weaknesses of the library to get the support for improvement of the library capacity. Externally, on the basis of togetherness spirit for the success of the library resource sharing among Islamic university libraries they have established the association (APPTIS). The association makes the library members become stronger collectively not only for lobbying but also for bargaining position especially with the Directorate of Islamic Higher Education.

Inevitably, that equality of library is the main requirement to be a part of library resource sharing member. At least there are two significant impacts of the togetherness spirit of library resource sharing on internal library member. First is the togetherness spirit become important factor that forces each library to be equal with other libraries in the use of the latest technology facilities to support the activities. The other one is the togetherness spirit also could be a reason for librarians to provide the distinctive and special collections. The internal impacts of the togetherness spirit must be striven by the head of library. Those two factors are key requirements of library resource sharing activities. Learning from the experience that many cases show that the sustainability of library resource sharing activities always fail because there is no equality between one library and the others in term of tools used and also collection imbalance. Therefore, now library resource sharing cooperation between Islamic university libraries is done by building institutional repository in each library. The development of the institutional repository is based on the spirit of open access. Several things that need to be completed in the program of cooperation through the open access institutional repository is to formulate rules that determine the rules of the game.

The other impacts of the togetherness spirit of library resource sharing cooperation on external aspect of library member is also done by library through regular meeting of library leaders. Through the meetings many themes could be discussed and solved together. The efforts of the APPTIS leaders that aim to overcome the various shortcomings faced by the members are able to attract the attention of the directorate of Islamic higher education to support the programs of APPTIS. One of the supports given by the directorate is the internship program for librarians that will be hold in several overseas libraries such as Australia, New Zealand. The program like this then was determined as an annual program. Every year there are around 12 librarians are selected and become delegation of APPTIS members to participate this program. This program provides librarians opportunities to gain insight and real-life working experience with corporate culture in an advanced library institution.

The togetherness spirit of the association is able to create various programs as an effort to improve the insights, knowledge, experiences and skills of association member librarians. Therefore, associations often regularly organize scientific events, workshops and training. All members of the association have equal rights in taking part in such events. All cooperation activities that participated by the member of APPTIS will provide a wealth of information about maps of strengths and weaknesses of each member. This mapping usually could be an argument for librarians to convince university leaders to give more attention and support libraries to equip them not only with advanced technology but also with proportional policies.

The state Islamic university libraries typically have uniqueness of characteristics, especially in term of the resources of Islamic studies. As an important factor of cooperation that togetherness spirit of information resource sharing among state Islamic university libraries become a power to enhance the capacity of state Islamic university libraries. Because of the same characteristics in the area of Islamic studies it encourages Islamic university libraries to be able to share each other. However it is not easy to create conducive atmosphere that could increase the library capacity. However the library resource sharing of Islamic universities still face some obstacles in doing cooperation between them. Some obstacles of the library resource sharing are there is still a sectoral ego within each library, weak of formal formulation of resource sharing agreement program, each library has no a special division in charge.

\section{CONCLUSION}

Spirit of togetherness in library resource sharing among Indonesia Islamic universities becomes the basis of power for each library members to improve the quality library services in both internal and external aspects. The establishment of Islamic academic libraries allows each library to share their resources one another. As an association affiliated to Islamic universities, APPTIS does not mean an exclusive association. APPTIS also often cooperates with several non-Islamic affiliated universities. Unfortunately, although the impact of togetherness spirit in the library resource sharing program among Islamic universities have given many benefits on both the internal and external aspects but it must be confessed that it could not be implemented optimally. Some obstacles in the implementation process of 
library resource sharing among Indonesia Islamic universities are a sectoral ego in some library members, inadequate agreement that govern the resource sharing program and most libraries no have a particular division that in charge for running theprogram.

\section{REFERENCES}

[1] P. L.Simmonds and Syed Saad Andaleeb, "Usage of academic libraries: The role of service quality, resources, and user characteristics - ProQuest," 2001. [Online]. Available: https://search.proquest.com/openview/ [Accessed:14-Oct-2017].

[2] J. Branin, France Groen, and Suzanne Thorin, "The Changing Nature of Collection Management in Research Libraries, "Aries Libr. Resour. Tech. Serv., vol. 4, no. 1,2000.

[3] M. L. Rice-Lively and J. Drew Racine, "The role of academic librarians in the era of information technology, "J. Acad. Librariansh., vol. 23, no. 1, pp. 31-41, Jan. 1997.

[4] V. A. Geronimo and C. Aragon, "Resource sharing in university libraries: A tool for information interchange,"Libr. Collect. Acquis. Tech.Serv., vol.29, no.4, pp.425-432, Dec. 2005.

[5] B. P. Panda, "The Dimension of Electronic Interlibrary Loan." Chinese Librarianship: an International Electronic Journal, 2010.

[6] K. Ameen, "Barriers in Collection Sharing among Libraries of Pakistan: University Library Managers' Viewpoint, "Libr. Ibrary Inf. Sci.Res.Electron.J., vol.18, no.1, pp.1-11, 2008.

[7] P. Tjitropranoto, "Kerjasama Perpustakaan dan Jaringan Informasi," presented at the Kongres Ikatan Pustakawan Indonesia III, Yogyakarta, 1983, p. 11.

[8] H. Gultom, Konsorsium Perpustakaan di Indonesia. Medan: Universitas Sumatera Utara, 2013.

[9] J. W. Creswell, Penelitian Kualitatif \& Desain Riset: Memilih diantara lima pendekatan. Yogyakarta: Pustaka Pelajar, 2014.

[10] L. J. Moleong, Metodologi Penelitian Kualitatif. Bandung: Remaja Rosdakarya, 2002. 